\title{
A glance at Spanish Embryology and Teratology during the XX Century through the academic life of Francisco Orts-Llorca (1905-1993)
}

\author{
JUAN ARÉCHAGA*,1, JUAN JIMÉNEZ-COLLADO² and DOMINGO RUANO-GIL 3 \\ ${ }^{1}$ University and Royal Academy of Medicine of the Basque Country, Bilbao, \\ ${ }^{2}$ Complutense University of Madrid and Royal National Academy of Medicine, Madrid and \\ ${ }^{3}$ University of Barcelona and Royal Academy of Medicine of Catalonia, Barcelona, Spain
}

\begin{abstract}
Francisco Ort-Llorca (1905-1993) was one of the most outstanding Spanish embryologists of the XX century. He was disciple of Henri Rouvière in Paris (France), Alfred Fischel in Vienna (Austria), Walther Vogt in Munich (Germany) and Pedro Ara in Madrid (Spain). From 1935, he was professor of Human Anatomy at the Faculty of Medicine of Cadiz, belonged then to the University of Seville (accidentally, in the University of Valencia, during the Spanish Civil War from 1936-1939) and, later on, at the Faculty of Medicine of Madrid (Complutense University) from 1954 to 1975. He was internationally recognized in anatomical sciences and stood out for his contributions to descriptive and experimental Embryology and Teratology, particularly in those aspects connected to the normal and pathological development of the heart and visual organs.
\end{abstract}

KEY WORDS: Francisco Orts-Llorca, Spanish Embryology, Spanish Developmental Biology, Spanish Anatomy, History of Biology in Spain

One of the more unjust facts on the history of Developmental Biology in Spain lies in believing that the interest for this subject has only recently started. Specifically, with regard to the introduction of the modern developmental genetics methods in some new model organisms like the fruit fly, a task where the Spaniards have made relevant contributions in the last half of the $X X$ century (see Ghysen, 1998, 2009, Martínez-Arias, 2009). Something similar has happened with other scientific areas in Spain. For instance, the disdain or unconscious hiding of the Spaniards contributions to Cytology and Histology before the great accomplishments of Santiago Ramón y Cajal (1852-1934) as it has been revised in a previous article is in this issue (see Marco-Cuellar and Aréchaga, 2009). In this regard, it must be reminded that, talking about Science, nothing and nobody emerge due to spontaneous generation, by chance or as result of a miracle, as erroneously wrote the great Spanish philosopher José Ortega y Gasset $(1906,1908)$ or the Spanish Nobel Prize Severo Ochoa (1995) to emphasize the merit of Cajal at his time. Such kind of opinions, only try to justify deficient historic information and to insist on them is nothing more than a futile exercise of sanctimoniousness (Laín-Entralgo, 1978) or masochistic lamentation (López-Piñero, 2006).

Nevertheless, it is also true that the appropriate historical research about the origin and development of the embryological and teratological studies in Spain is still to come, since their approaches up to now has only been sporadic and very superficial (i.e.: Aréchaga et al., 1976 a,b; López-Piñero, 1971; LópezPiñero et al., 1979, 1983). Particularly, we have paid no attention to the long process of introduction of their experimental methodology and the new conceptual orientations during the $\mathrm{XIX}$ and $\mathrm{XX}$ centuries. The scientific biography and contributions of Francisco Orts-Llorca (1905-1993) can be a significant example of what the mythologizing process of some today Spanish developmental biologists hides.

\section{Scientific biography}

Francisco Orts-Llorca was born in 1905 at Tampico, in the Atlantic cost of Mexico, where his father, a Spanish merchant navy officer, developed his professional work as harbor pilot. Some time later, he moved with his family to Veracruz, the most important Mexican harbor. However, the father had to leave the job very soon because of the difficulties imposed to the foreigner workers by the Mexican Revolution (1910-1917). So, the hole family had to come back definitely to Spain, when the little

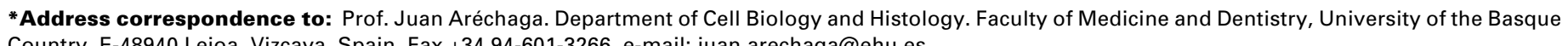
Country, E-48940 Leioa, Vizcaya. Spain, Fax+34 94-601-3266. e-mail: juan.arechaga@ehu.es

Final author-corrected PDF published online: 4 September 2009.

ISSN: Online 1696-3547, Print 0214-6282 

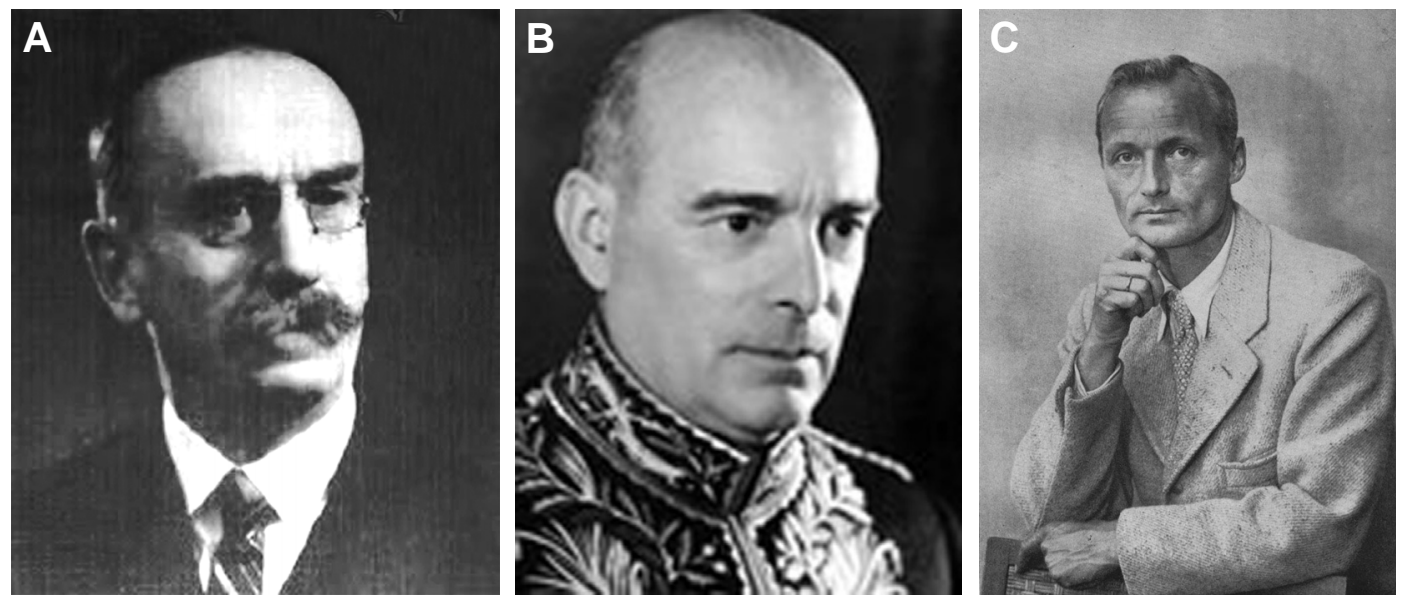

Fig. 1. Henri Rouvière (18751952) (A), Pedro Ara-Sarriá (1891-1973) (B) and Walther Vogt (1888-1941) (C), together with Alfred Fischel (1868-1938), were the main researchers who shaped the scientific personality of Francisco Orts-Llorca in the areas of Anatomy and Embryology.
Francisco was only seven years old, and they provisionally settle down in their ancestors land, Benidorm, a small fishing village then in the south of the province of Valencia, very different from the present mega tourist city. Soon after, they moved to the province capital city, Valencia, where they could count with a better job for the father and good scholar centers for the children.

Thanks to a fellowship offered by an aristocrat, the Count of Altea, friend of the family, the young Orts-Llorca moves later to the prestigious Jesuit School of ElPalo, name of a residential neighborhood of Malaga (Andalusia), where he finishes his studies previous to University and acquires a sense of order and discipline so useful in his future professional activity. Later, as it also happened at a time with the adolescent Santiago Ramón y Cajal, his father obstinacy to avoid an early romantic vocation to go along another way (he intended to continue the family tradition of being a seaman and, therefore, to study at the Military Naval Academy of San Fernando, Cadiz) and thanks to his good relationships with the rural doctor of Benidorm, where he used to go on holidays, finally decides to study Medicine at the University of Valencia between 1921 and 1928. There he finds an excellent team of teachers, particularly the professor of Topographic and Surgical Anatomy Jesús Bartrina-Capella (1864-1974) who will have a great influence in his professional future. During that period, Francisco Orts-Llorca obtained excellent marks and some student awards, apart from being an active collaborator of the Chairs of Anatomy and Surgery.

In 1928, after finishing his studies at the University of Valencia, the father firm decision is present again in his life financing a staying in Paris to specialize with the prestigious French surgeon Armand Gosset (1872-1944), professor of Surgery at the Faculty of Medicine of Paris, in the Hôpital de la Salpêtrière;stage which brings a great economic effort for the family. Simultaneously, he started to prepare his doctoral thesis under the guidance of Henri Rouvière (1875-1952) (Fig. 1), professor of Anatomy at the same Faculty of the Université de la Sorbonne, who was at that moment working in his important monograph Anatomie des Lymphatiques del'Homme(1932). The staying in Paris of Orts-Llorca should be, in consequence, very active and fruitful, since in the mornings he usually went to the operating room and to the surgery clinic and, in the afternoons, he hard worked at the Anatomy laboratory. But, his cooperation with professor Rouvière gains increasing importance and decides definitively his professional future towards Anatomy, giving up the Surgery, although, some years later, he will be forced to retake it again. Thus, Francisco Orts-Llorca makes a great professional, scientific and researching effort in Paris, taking part even in teaching at the Uyniversity and presenting his research results at the Academy of Medicine. As result of this French stage, he also publishes a dozen of scientific articles in French journals and some more in Spanish ones, which appeared between 1929 and 1933. These publications deled on descriptive anatomy of the human lymphatic structures and on the biological meaning of the polygastric muscles (Fig. 2). Simultaneously, Orts-Llorca gets fascinated by the collection of serial histological sections of human embryos at different stages of development, that Prof. Rouvière was getting ready at that time and which will leave an imprint for his future career as independent researcher.

Francisco Orts-Llorca comes back to Spain in 1930 and joins the Faculty of Medicine of the University of Valladolid as an Assistant of one of the Chairs of Anatomy. In 1931, he finally defends his doctoral thesis under the title "Linfáticos de los órganos anexos del aparato de la visión" (Lymphatics of eyeassociated organs) at the Central University of Madrid, which at that time, was the only Spanish university that granted the academic title of Doctor. Lately, he decided to specialize in Embryology and, for that, he did two short postdoctoral stages between 1931 and 1932 at the Medical Schools of Paris and Berlin. Later, from 1933 he spent more than a year in Vienna, with the scientist of Czech origin Alfred Fischel (1868-1938), professor of Embryology at the Faculty of Medicine, who had recently published his well-known Lehrbuch der Entwicklung des Menschen (1929). In all these postdoctoral stages, he was awarded with fellowships from the Junta para Ampliación de Estudios $e$ Investigaciones Cientificas, an entity founded and presided over many years by Santiago Ramón y Cajal and, after him, by the prestigious entomologist Ignacio Bolívar y Urrutia (1850-1944), who introduced genetical studies in Spain (see Martínez-Arias, 2009), until the Spanish Civil War of 1936-1939. This organization was then the only Spanish public agency granting researchers to be trained abroad. In order to obtain this, Orts-Llorca counted with the support of two well-known scientists who recommended him for the stipend: Pío Del Rio Hortera (1882-1945) and Pedro Ara Sarriá (1891-1973).

In Vienna, Francisco Orts-Llorca has the occasion to deeply study different aspects of the human embryo development, since the Second Institute of Anatomy of the Medical Faculty had then 

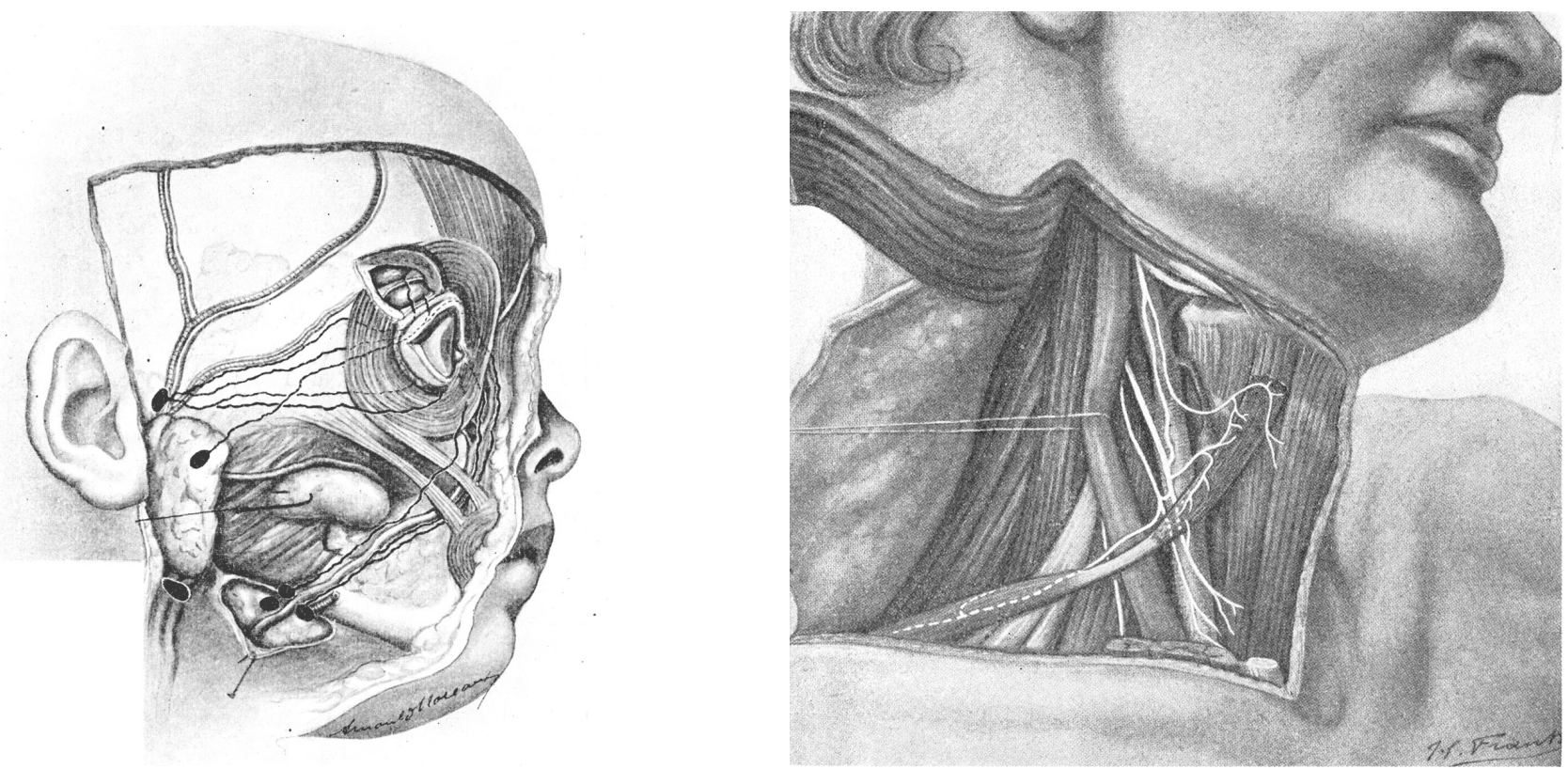

Fig. 2. Images corresponding to representative anatomical works of F. Orts-Llorca, under the direction of Henri Rouvière, during his first stage in Paris (1928-1930). His studies mainly deal with ocular lymphatics and the biological significance of polygastric muscles. In one of his publications, the peripheral lymphatic vasculature of the cornea is described for the first time. This is frequently referred to by ophthalmologists with his eponym (limphatic annulus of Orts-Llorca).

the largest embryological collection in the world. There he learns, among others, the Gustav Born's wax plate method (1883), with their subsequent improvements (specially, those of Karl Peter, 1922), for the plastic three-dimensional reconstruction of embryo structures from the piled two-dimensional layers of wax plates cut out (Fig. 3). This was already done from an objective point of view, far away from the subjective "projective method" of Wilhelm His (1887), which required a great ability to draw and was exposed to many errors of interpretations, like happened in his models of human heart development (see Hopwood, 2002). Orts-Llorca also comes into the knowledge of comparative embryology, and learns how to use and interpret the embryo development tables; particularly the great encyclopedic work in 16 volumes edited by Franz Keibel (1861-1929) under the title of Normentafeln zur Entwicklungsgeschichte der Wirbeltiere (see Hopwood, 2007). The same author had published too an excellent and wellillustrated Human Embryology textbook (1910-1912) together with Franklin P. Mall (1862-1917).

In the prestigious Viennese Second Institute of Anatomy at Währingerstrasse was at the time, besides the great anatomist and embryologist Ferdinand Hochstetter (1861-1954), his successor at the Institute direction from 1933 Eduard Pernkopf (1888-1955) (Fig. 4), who was then starting to prepare his famous Atlas of Topographic Anatomy (Pernkopf and Pichler, 19371960; Williams, 1988; Angetter, 2000). Both circumstances, makes us suppose that both also would had

Fig. 3. Plastic reconstruction by the Born-Peter method of the central nervous system and the chondrocraneus of the Rx human embryo of $23.5 \mathrm{~mm}$, under the direction of Prof. Orts-Llorca in the Faculty of Medicine of Cadiz (MartínezRovira, 1947). equally a great influence in the embryological and anatomical training of Orts-Llorca, who, as a result of his staying in Austria, would publish his first embryological articles in German journals (1933, 1934a, 1934b, 1934c, 1934d).

At that time, the city of Vienna still lived on the age of great scientific and artistic splendor from the old Austrian Empire (its University even still counted with six Nobel Prize winners) in spite of the difficult politic situation that existed since the decade of the 20 s, and especially after the great depression of 1929. Thus, street riots, promoted be Marxist organizations at the so-called "Red Vienna", were frequent and lead to Parliament dissolution and the instauration of an authoritarian regime in March of 1933. However, the Faculty of Medicine was still one of the best in Europe regarding the clinical practice and biomedical research as well. Vienna was besides, a cosmopolitan city where youths from all over the world went to be educated, both in science and in music or art and, therefore, our young Spanish embryologist enjoyed an excellent cultural atmosphere for his personal and professional development. Orst-Llorca, who kept along his life a
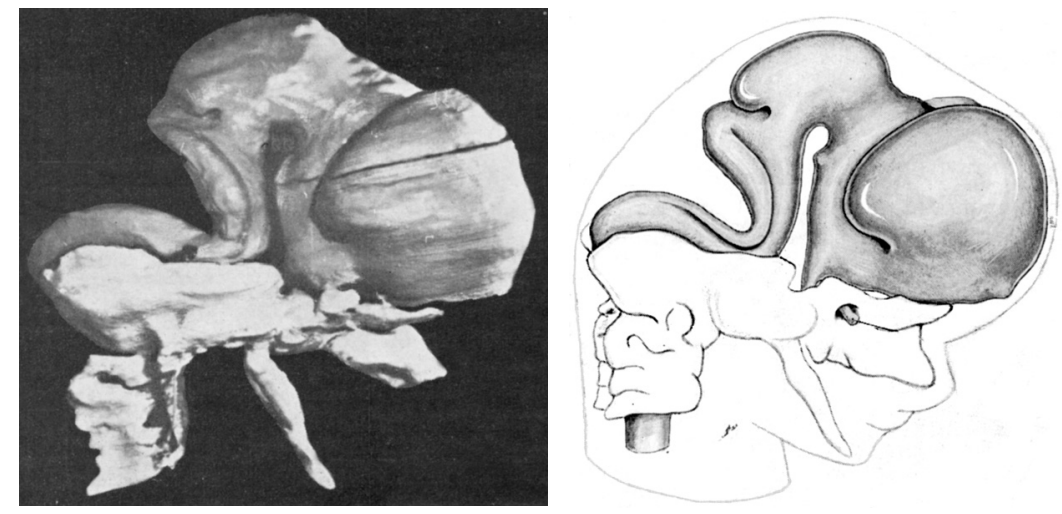

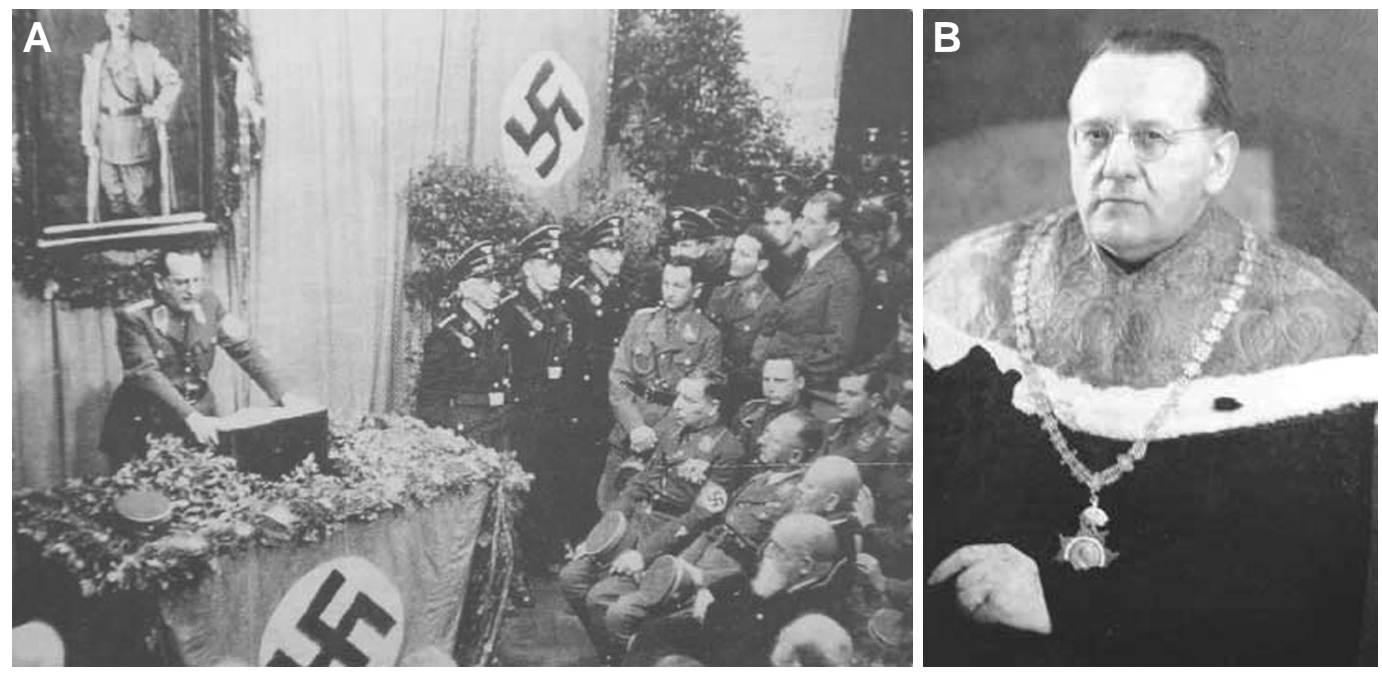

Fig. 4. Eduard Pernkopf (18881955), Director of the Second Institute of Anatomy of the Vienna Medical School at the time of the visit of F. Orts-Llorca in 1933-34. Pernkopf was a member of the NSDAP, the Austrian Nazi party, forbidden by Canciller Dolfuss in 1934. (A) Lecturing in 1938, as Dean of the Vienna Medical School, after the German Anschluss, under a portrait of Adolf Hitler. (B) As Rector of the University of Vienna from 1943.

After the war, Prof. Pernkopf was imprisoned near Salzburg for two years and lost all his official academic positions, although he was still working on his famous anatomic Atlas until his death. His disciple. Alexander Pichler, published the last volume of this magnificent work in 1960.

great love for the chamber music, met there several Spanish youngsters under identical circumstances and who later would be famous names in the Medicine of his country as, for example, the surgeon Mariano Fernández-Zúmel, the historian Pedro LaínEntralgo, the otorhinolaryngologist Rafael Bartual-Vicéns (son of the first disciple of Santiago Ramón y Cajal) or the psychiatrist Juan Rof-Carballo, among others. Vienna was also the city where he met to his future wife.

At the beginning of 1934, the Austrian political situation starts to deteriorate to a great extent in the way of a real civil war, with frequent riots in the streets between Marxist or National-Socialist groups and the Government troops from the Vaterländdische Front, founded as an association of conservative parties by Chancellor Engelbert Dollfuss. He would, finally, become a prisoner and assassinated by the Austrian Nazis in July of that year, as a prelude for the later hitlerian Anschluss of 1938. Due to these serious circumstances, even some members of the Viennese Second Institute of Anatomy were enthusiastic supporters of Nazi policies (Angetter, 2000) (Fig. 4), Orst-Llorca decides to go back to Spain at the end of his fellowship and joins the Faculty of Medicine of the Central University of Madrid as Assistant of the Chair of Anatomy of professor Pedro Ara (Fig. 1), who precisely had recommended him, some time before, to go to Vienna (Dr. Ara had been itself a former pupil of Prof. Hochstetter in 1924). A bit later, at the beginning of 1935, he obtains the Chair of Anatomy at the Faculty of Medicine of Cadiz, at that time dependant of the University of Seville, getting married immediately after to his Austrian girlfriend.

But, Francisco Orts-Llorca considers that his embryological education is still insufficient according to the experimental point of view, which was then an up-to-date topic. For this raison, in the summer of 1935, he went to the Department of Zoology at the University of Munich in order to do a stay with Walther Vogt (18881941) (Fig. 1), who had described in 1929 his famous technique of "fate mapping", marking superficial regions of amphibian blastulas with vital stains and observing later their displacements during gastrulation (Fig. 5). Vogt was besides, since 1925, co-editor of the influential journal Wilhelm Roux Archiv für
Entwicklungsgmechanik der Organismen, together with Hans Spemann (1869-1941), who would receive the Nobel Prize in Physiology and Medicine in 1935 for his discovery of primary embryonic induction phenomenon, together with Hilde (Pröscholdt) Mangold (1898-1924); see in this regards Fässler (1996), Hamburger (1996) and Sander and Faessler (2001). Orts-Llorca was so interested in continuing his training on experimental techniques, that in 1936 The Rockefeller Foundation granted him a fellowship in order to do research with Johannes Holtfreter (19011992), a former disciple of Hans Spemann in Freiburg, who had just join the Zoology Department at the University of Munich. In order to do this, Orts-Llorca should go to Germany on the $21^{\text {st }}$ of July that year, but... the $18^{\text {th }}$ of the same month the Spanish Civil War (1936-1939) breaks out followed by the Second World War (1939-1945), so his important scientific plans in Germany defini-

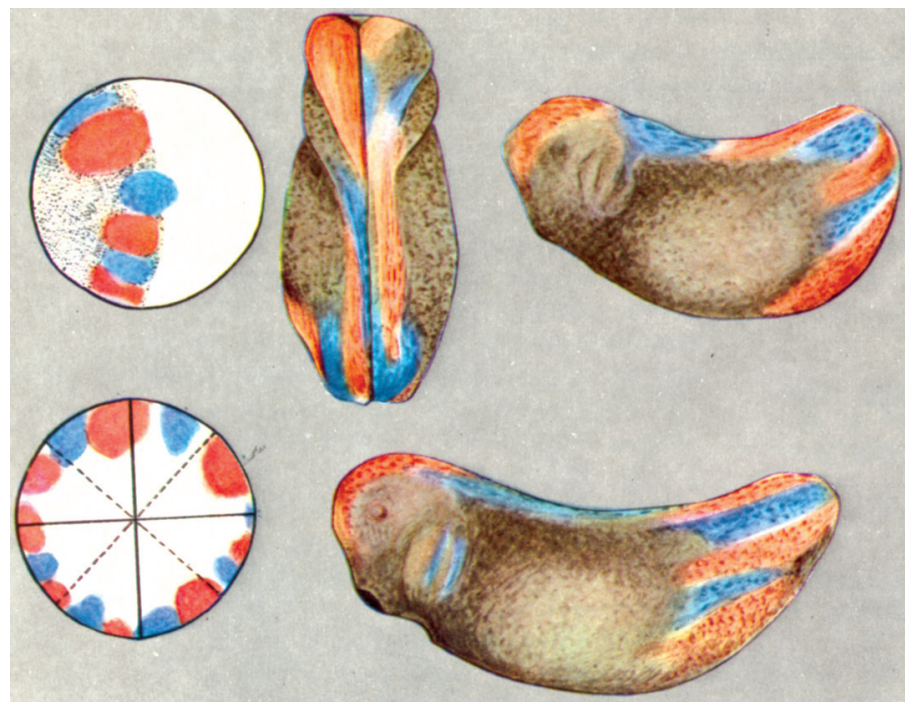

Fig. 5. Vital staining of an amphibian embryo according to Vogt's technique in order to study its prospective areas after gastrulation (OrtsLlorca, 1975). 


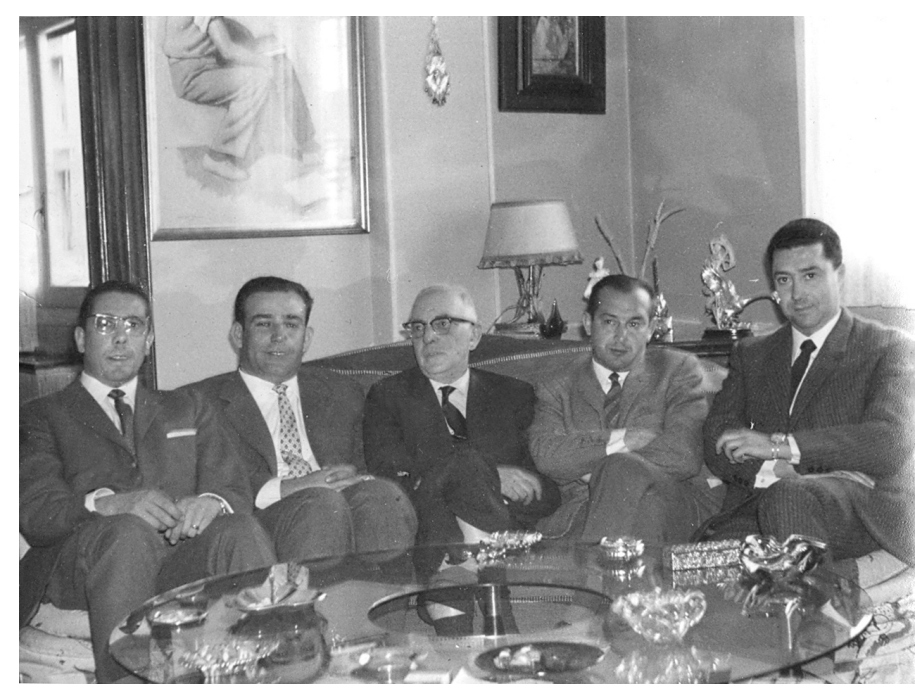

Fig. 6. Francisco Orts-Llorca, in the center, at home with four of his main collaborators (ca. 1964). From left to right: Narciso Murillo-Ferrol, Domingo Ruano-Gil, F. Orts-Lorca, José M. Genis Galvez and Juan Jiménez-Collado. All, with the exception of Murillo-Ferrol were former students of his at the Medical School of Cadiz (University of Seville).

tively failed.

During the Spanish Civil War, Francisco Orts-Llorca had to joint the Faculty of Medicine of the University of Valencia as professor of Anatomy, the nearest one to Benidorm (where he was spending his holidays during the summer of 1936) because the Faculty of Medicine of Cadiz was then in the so-called "National Zone" and he would not travel there without going through the war front. For that reason, he was also obliged to cooperate with the "Republican Side" in the "Red Zone", working as war surgeon in Valencia and Altea and suffering, because of that, some reprisals at the end of the conflict, although not very important ones (see Otero-Carvajal, 2001). In spite of these serious circumstances, Orts-Llorca did not interrupt his research activity at the Faculty of Medicine of Valencia and was even able to publish some articles during the war (1936a, 1936b, 1937a, 1937b, 1938). Finally, when the Spanish conflict comes to an end, he occupied his former Chair at the Faculty of Medicine in Cadiz, where he will suffer the hardship of the postwar period. Thus, publications by OrtsLlorca until 1954, date when he moves to the Central University of Madrid, show the scant resources he counted on to develop his academic work which. Additionally, had to combine it with his private practice as surgeon to increase his low academic salary. Nevertheless, he succeeded in making up a group of enthusiastic young collaborators (Fig. 6); enlarge his histological serial collection of embryos of different ages (a work he had started in Valencia, during the war!), doing some significant contributions to the area of descriptive embryology and assays dealing with experimental embryology. He takes advantages too, from these circumstances, to write his important treaty on Human Anatomy (1944-1952).

The change to the Central University of Madrid (Fig. 7) will mean for Orts-Llorca his consecration as the most important embryologist of the country, as well as his international renown. $\mathrm{He}$ also starts there his most prolific period as experimental embryologist, which had been delayed by the previously mentioned circumstances. This way, intentionally he starts that period in Madrid with a series of lectures financed by Fundación Valdecilla (1955) about what at that time was still called Developmental Physiology according to the terminology suggested by Hans Spemann (Entwicklungsphysiologie), who preferred that name to Entwicklungsmechanik, used by Wilhem Roux (see Fassler, 1996). Later, those lectures were captured in a small monograph (1956) under the title "La Fisiología del Desarrollo y su importancia en Biología" (Developmental Biology and its role for Biology) which was very influential in Spain, since it was the first monograph dealing with the experimental embryology published in our country (Fig. 7). At that period, he also translated from German a well-known text written by the Swiss anatomist and embryologist Gian Töndury (1958). We know from that time he completed a research stage in Baltimore, Maryland (USA), at the Department of Embryology of the Carnegie Institution of Washington, during three months, from July 1959 . The purpose of this stage was the study the outstanding Collection of Human Embryos collected by

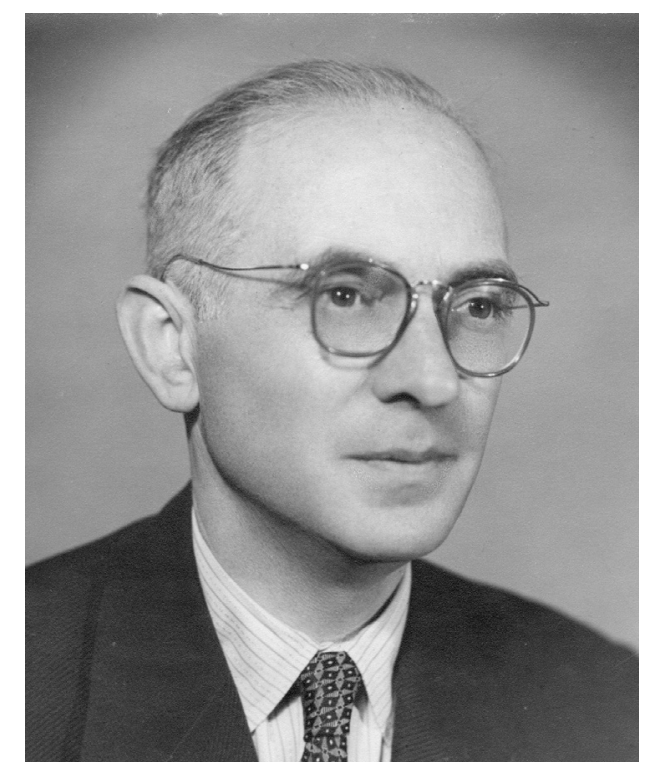

Fig. 7. Portrait of Francisco Orts-Llorca (ca. 1954) at the time of his arrival to the Chair of Anatomy of the Madrid Medical School and cover page of his influential monograph "La Fisiología del Desarrollo y su importancia en Biología" (Developmental Physiology and its role in Biology). (1956).

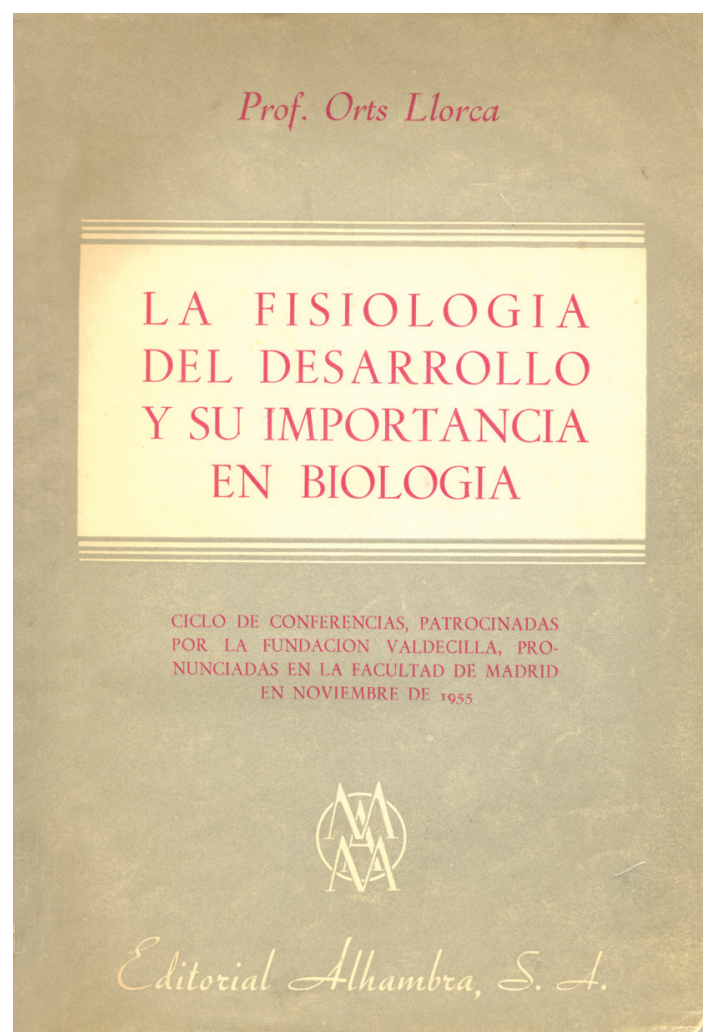


Franklin P. Mall at the beginning of the XX century and, later, significantly increased and organized by George L. Streeter and Ronan O'Rahilly (see Hopwood, 2007). In the same journey, Orts-Llorca also visits and meet personally some important American embryologists and anatomists at the Departments of Zoology (Dr. Twitty) and Anatomy (Dr. Greulich) of the Stanford University in California, at the Rockefeller Institute (Dr. Weiss) and the Department of Anatomy (Dr. Copenhaver) of Columbia University of New York and in the Department of Zoology of the Washington University at Saint Louis, Missouri (Dr. Hamburger). Some time later, in 1962, he went again to the Carnegie Department of Embryology in Baltimore (to visit Dr. De Haan) and, in 1968, he also visited the Department of Zoology of the Northwestern University at Chicago (a stage with Dr. Moscona) and the Department of Anatomy of the Medical University of Ohio at Toledo (to visit Dr. Di Dio).

Along his professional career, professor Orts-Llorca supervised more than sixty doctoral theses, mainly about embryological topics and he also published, besides the previously cited textbook and monograph, almost two hundred articles in professional and circulated journals and newspapers (see a selected bibliography on Embryology and Teratology at the end of this article). The international impact of his work is well reflected in the great number awards he received, as well as invitations to visit universities and other scientific institutions, or to take part in congresses, curses and seminars in Argentina (Buenos Aires, Cordoba, Rosario, Corrientes), Belgium (Brussels), Finland (Helsinki), France (Paris), Greece (Zante), Israel (Jerusalem), Mexico (Mexico City) Nederland (Leyden), Panama (Panama City), Portugal (Lisbon), United Kingdom (London), Switzerland (Interlaken) USA (San Francisco, Minneapolis, New York, Baltimore, Chicago, Toledo) and Venezuela (Caracas), apart from his cooperation in several courses organized by Universities and research centers in Spain. In the same way, he received a great number of academic distinctions and decorations, among which should be highlighted the Honoris Causa doctorate by three Universities and his appointment as a member of the Spanish RoyalNational Academy of Medicine(Fig. 7) and other prestigious national and foreign institutions, as well as being invited to joint to the Editorial Board of influential journals of Anatomy and Embryology. In his last active academic period, he was even appointed academic Director of the Hospital of the Central University of Madrid (1969-1975), a position Orts-Llorca still combined with his research activity. After his official retirement in 1975, Don Francisco, as respectfully and lovely we used to call him, kept on going to the laboratory in his former Chair, and develop besides different academic activities, almost until his death in 1993 , at the age of 88 years.

\section{Contributions to Embryology and Teratology}

The analysis of the scientific production by Francisco Orts-
Llorca reveals three periods very well defined. In the first one, between 1928 and 1931, his activity is focused exclusively on the specific aspects of the descriptive human anatomy, mainly in relation to his doctoral thesis about the lymphatic organs of the eye and associated structures. In the second one, after his postdoctoral training in Paris, Berlin, Vienna and Munich (1932-1936), he concentrates on the specific aspects of descriptive Embryology and Teratology. Finally, following the forced long pause of the Spanish Civil War plus the Second World War (1936-1945) and the difficult post-wars years, he starts his most prolific activity in the field of experimental Embryology and Teratology, particularly after 1954. However, he never left the study of descriptive aspects, derived from the careful microscopic analysis and modeling reconstruction of his extensive collection of human embryos and other mammals.

The importance that had, at that time, to work in Human descriptive Embryology and Teratology, particularly during the first phases of development, can be easily understood if we take into account the important fact that, until 1954 (Hertig et al.), the best-preserved human embryo studied was that described by Wilhelm von Mollendorff (1921) of about 18 days of age. At that moment, it was only possible to get embryos in a fortuitous manner, after spontaneous abortions, hysterectomies or histopathological exams of endometrium samples. In those circumstances, the human embryos normally arrived to the embryological laboratories under bad preservation conditions. Even, the rareness of the youngest human embryos under study, implied that those were known by the name of the gynecologist or the researcher who obtained or described them in a publication; i.e.: the Kleinhans embryo, the Hochstetter embryo, the TeacherBryce embryo, the Miller ovum, etc. It was even doubted about the existence or not of the blastocyst stage in human embryos! (Grosser, 1922). A very different situation from what happens nowadays after the arrival of the techniques of in vitrofertilization and culture of human embryos or the legal authorization of the 
A

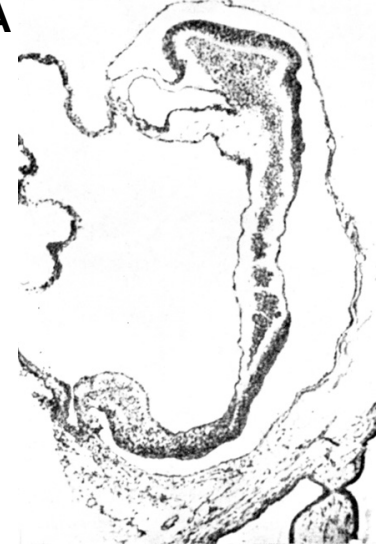

B

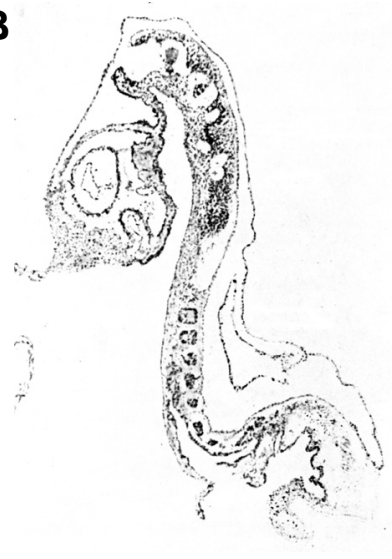

Fig. 9. Histological sections of two representative human embryos at the Embrytheca Orts-Llorca of the Medical School of the Complutense University of Madrid (Spain). (A) CA embryo with 4 pairs of somites. (B) Cano embryo with 14 pairs of somites.

abortion techniques in many countries. Therefore, the knowledge about the first phases of human egg pre and post-implanted or about the early human organogenesis was incomplete in many aspects until very recent times. Only under this perspective we can be understood Orts-Llorca's great interest, and of the rest of embryologist of his time, in creating a wide histological collection of serial sections of human embryos (Embryotheca) and to promote its constitution in other laboratories to be able to fill the gaps between human developmental stages. Due to this, the important Embryotheca Orts-Llorca from the Department of Anatomy and Embryology at the Complutense University of Madrid, keeps on being at present the most important one in the country (Fig. 9). An estimation about the number of the histological slides of it showed, at the beginning of the seventies in the $\mathrm{XX}$ century, the number of more that one hundred thousand slides, coming from a hundred or so human embryos at different stages of development, some of them very young and, generally, in a quite acceptable preservation state. There, we can found excep- tional specimens like a human embryo with three pairs of somites and a $10 \mathrm{~mm}$ anencephalic embryo. In the selected bibliography at the end of this article, there are references to the Orts-Llorca main contributions to descriptive Embryology and Teratology, fields in which he was very interested in all along his scientific career. Among them, can be highlighted the descriptions of normal human embryos from the Streeter horizons XI and XII and several kinds of congenital malformations at early development stages (1934d, 1937a, 1938, 1948b, 1949, 1950, 1952d, 1953a, $1954 a, 1955 a, 1955 b, 1957 a, 1957 b, 1958 b, 1958 c, 1958 d$, 1959b, 1960c, 1962c, 1962d, 1962e, 1962f, 1964a, 1964e, 1981b, $1982 b, 1983 a, 1983 b)$. Some reviews of human congenital malformations and teratomas are also of interest (1936a, 1946b, $1963 b, 1970 e, 1985)$. In the last period of his life, Orts-Llorca even published a catalogue of the embryo and fetus of the histological collections existing in Spain (1984) and from which his have been the pioneer.

Among Francisco Orts-Llorca's most significant contributions to Experimental Embryology and Teratology, apart from the impact that his previously mentioned monograph of 1956, we should highlight several studies. For instance, on the inductive activity of dead tissues, confirming previous experiences of Sulo Toivonen with dead mammals tissues in amphibian embryos (Aréchaga, 1989), but Orts-Llorca used boiled and dried up human testis tissues with chick embryos (1948d). He also looks for the embryonic effects of synthetic hormone agents like Testoviron ${ }^{\circledR}$ and Cortiron ${ }^{\circledR}$, enzymatic products (hyaluronidase, I-asparaginase) or inorganic salts (lithium chloride, used for the Holtfreter exogastrulation experiments), studies that were carried out mainly with chick embryos (1944a, 1948b, 1956a, 1974f, 1979c, 1980a, 1980b). But, where Orts-Llorca specially stood up was in the usage of delicate techniques of microsurgery to investigate the inductive phenomena, embryo regulation and morphogenesis (1960b, 1962c, 1963c, 1963f, 1967a, 1969b, 1971b, 1971c, 1973a, 1978c, 1974a, 1974b, 1974c, 1975a). These methods were combined in many occasions with very advanced techniques for that moment, like time-lapse cinematography (1967b), electron microscopy (1967e, 1969c), radioactive isotopic labeling (1967f, 1968a, 1968b, 1969a, 1970b), in vitro
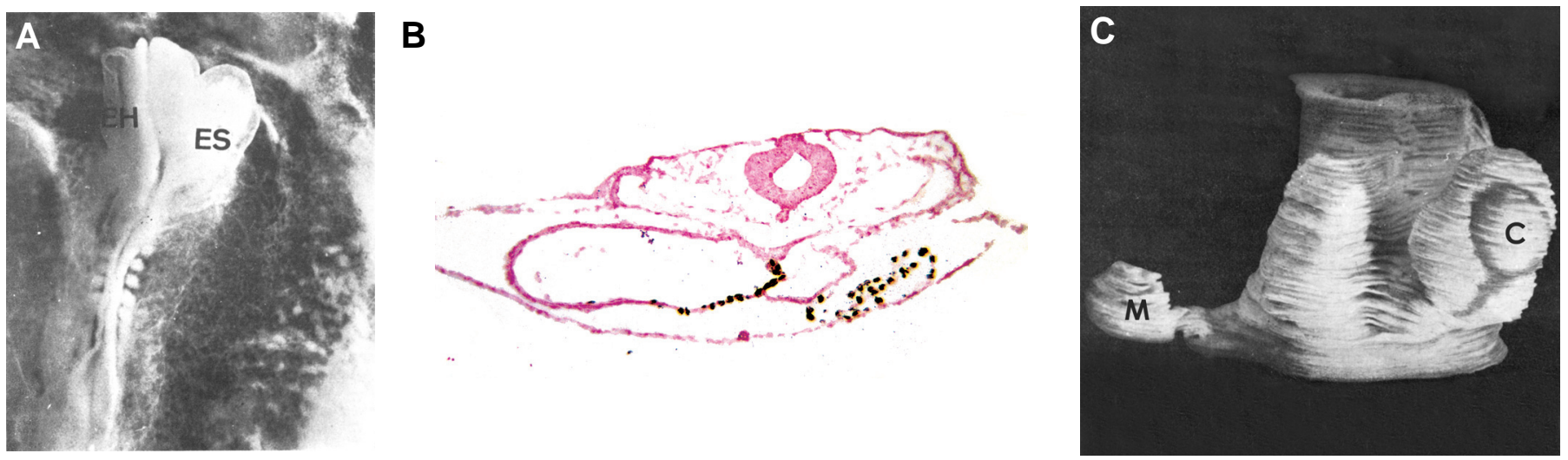

Fig. 10. Some examples of the experimental work of F. Orts-Llorca and collaborators. (A) Experimental bicephalia after quail Hensen node transplant under the ectoblast of a chick embryo at the primitive streak stage of development (Orts-Llorca and Cuevas, 1974). (B) Development of a supplementary heart in the chick embryo, after a heterologous graft of the cardiogenic region labeled with $\mathrm{H}^{3}$ thymidine in the celomic cavity (OrtsLlorca and Jiménez-Collado, 1969). (C) Wax plastic reconstruction of an experimental microphthalmia (M) produced after left vitelline vein section in a chick embryo, by the Born-Peter method (Orts-Llorca et al., 1959). C is the lens of the healthy eye. 
culture of disaggregated/reaggregated embryonic tissues (method of A. Moscona and H. Moscona, 1952) or the quail/chick marker system (Le Douarin, 1969). All of these, combined with meticulous microscopic descriptions of his discoveries (Fig. 10). Orts-Llorca also wrote some reviews on basic concept of cell differentiation and embryonic development (1953b, 1955b, 1966b, 1967d, 1971a, 1972, 1990) and historical and biographical approaches (1956d, 1973c, 1975b, 1975c, 1988).

Among his numerous publications focused on specific developmental and teratological aspects of vertebrate organs and systems, both descriptive and experimental, we can pointed out below those referring to heart and visual organs, although he also made significant contributions to the central nervous system and other organic systems.

In the publications about heart development, outlines in first place the description of an early stage of cardiac development, called since then plexiform phase, described by Orts-Llorca and collaborators (1960c) in three and four pairs of somites human embryos. This primitive cardiogenic area is organized as solid groups of mesenchymal cells, later hollowed and fused together in a cranial-caudal sequence (Fig. $11 \mathrm{~A}, \mathrm{~B}$ ). Later on, this cell plexus would lead to a sole and medial myo-endocardic tube; a peculiarity that distinguishes man from other vertebrates like birds in which the first sign of heart development is the fusion of two independent myo-endocardic tubes in the middle line of the body. Other important descriptive papers are his contributions to the knowledge of the precise wall up of cardiac cavities and their embryonic evolution, the development of myocardium vascularization and innervations and the mechanistic interpretations of some human congenital malformations (1944b, 1951, 1952a, 1954a, 1959b, 1975d, 1976a, 1978a, 1979a, 1982a, 1982b, 1983b, 1986). From the experimental point of view, we should stressed the important research about the following subjects: a) the determination and regionalization (Fig. 11C) of the heart's prospective area (1964b, 1967a, 1967b, 1967c, 1967g, 1968a, 1968b, 1969a, 1970a, 1970b, 1975a 1978c,); b) the developmental mechanisms of avian cardiac tube fusion (1964d); c) the determinant factors of embryonic cardiac polarity (1966a, 1967b) and cardiac tube curvatures (1967a, 1970a); d) the important discovery of the inductor role of endoderm in cardiac differentiation (1963a, 1963c, 1963d, 1963e, 1964e, 1965c) as well as the regulative function of neighbor structures, as the neural plate and its derivatives (1964c, 1965a, 1969b, 1974a); e) the cytological characteristics of the cardiac myocytes during their

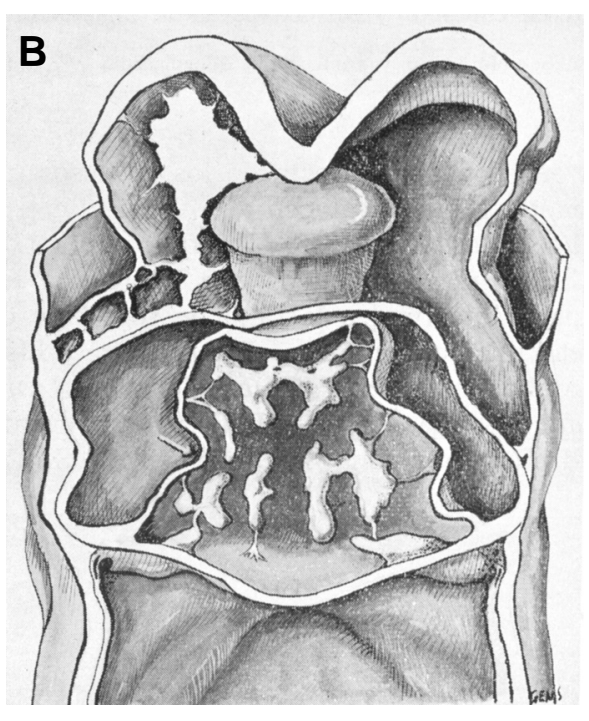

Fig. 11. Illustrations from contributions to descriptive cardiac development by OrtsLlorca and collaborators. (A) Histological section of the cardiogenic area of a human embryo with 4 pairs of somites (Orts-Llorca et al., 1960). (B) Three-dimensional reconstruction of the same stage of cardiac development (Orts-Llorca, 1967). (C) Regionalization of the cardiac prospective area at Hamburger-Hamiltonstage stage 6 (Orts-Llorca, 1970). differentiation (1969c, 1973a). This approach also include some interesting reviews on the subject (1962a, 1962g, 1962i, 1970c).

Regarding the studies on the embryonic development and malformations of the sense organs, Orts-Llorca and his collaborators also stood up successfully in the study of the visual organs, both through descriptive and experimental approaches. Among them, we can mention the following: a) the experimental evidences of the early determination of optic vesicles after transplantation of them in ectopic places of the embryo and, also, about the inducer activity of pre-cordal mesoderm (1971c); b) the experimental production of cyclopia (1944a) and microphthalmy $(1959 a)$; c) the demonstration of the ocular and prosencephalon regeneration capacity after half removal of the neural plate (1969b); d) the experimental proof of the inhibitory action of the neural retina on the pigment epithelium (1960b) (Fig. 12); e) the independent development of some ocular annexes, like the proper eye musculature and the nasolacrimal ducts $(1969 b) ; f)$ the effect of removal of the Hensen node on the differentiation of the optic placode (1971c); g) detailed teratological descriptions, particularly of cyclopia (1952d, 1953a, $1955 a, 1957 b, 1964 a, 1964 f, 1983 a)$, retina malformations (1960a) and h) some cell differentiation studies (1974d). Other minor contributions to the development of other sense organs are the demonstration of the inductive capacity of cephalic mesoderm on the olfactory placodes (1961b), vascularization of the inner ear (1932a, 1933d) the teratological description of 
a case of arhinencephalia with monorhinia at an early stage of development (1962e), studies on the differentiation of auditory placodes (1962b, 1965b) and a description of the early stages of the vestibular system (1976b) and ear bones development (1979b).

Different aspects of the development of the Skeletal System were of interest for Orts-Llorca and collaborators. For example, the origin, evolution and malformation of the backbone curvatures (1934c, 1957a) and the vertebral and head bones development (1941, 1946a, 1962d, 1969d, 1970d). Singular teratological descriptions (1950a) and the experimental productions of limb duplicities (1963f) were also of his interest. Nervous system morphogenesis was an aim in his research, especially in the last years of his academic life. In that sense, he dealt with the mechanism of primary induction (1974b, 1974c) and normal development of cerebellum (1977b), mamillary bodies (1977c), locus coeruleus and area postrema (1980c), spinal ganglia (1934b) as well some cytological and teratological studies and reviews (1937a, 1944c, 1948a, 1948c, 1949, 1950a, 1956c, 1974 e). Finally, we can bring forward that Orts-Llorca is also the author of some minor descriptive and experimental works or reviews about the development of endocrine glands (1954b, 1958a), lung and related structures (1932c, 1933a, 1933b, 1933f), embryo vascularization (1932b, 1933c, 1933e, 1934a, 1936b, 1937b, 1959b), digestive system (1950b, 1952b) and gonadal organs (1952c)

We cannot close the study of Francisco Orts-Llorca's academic contributions to Embryology and Teratology without highlighting, at least briefly, the great importance that his textbook "Anatomía Humana" (Human Anatomy) had in Spain and the Hispanic America (Orts-Llorca, 1944-1952; with five posterior editions in 1959, 1963, 1972, 1977 and 1981). The analysis in detail of this great work would deserve a monographic and deeply study, but, in synthesis, we can briefly say that it represented the incorporation of the innovative ideas in modern human anatomy, mainly on ontogenetic, comparative and physiological bases. This text can be considerer the Spanish adaptation of the integrating view of the biological human morphology (morphogenetic, structural and functional) intro-

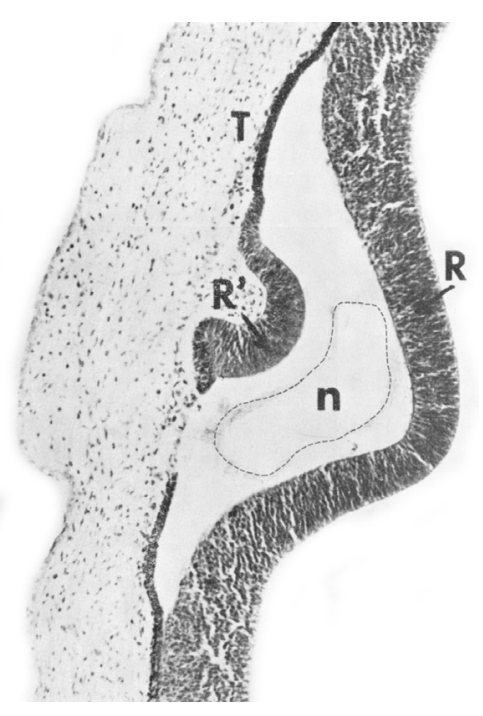

Fig. 12. Experimentally induced pigment epithelium differentiation to neural retina, after physically avoiding cell contacts between both layers with a thin nylon thread in chick embryos. (R) Neural retina, (T) pigment epithelium, $(n)$ nylon thread, $\left(R^{\prime}\right)$ experimentally induced neural retina differentiation in the pigment epithelium (OrtsLlorca and Genis-Galvez, 1960). duced by the German anatomists Herman Braus (1867-1924) and his disciple Kurt Elze (1885-1972) in their well known collaborative treaty Anatomie des Menschen (1920-1935) and by Alfred Benninghoff (1890-1953) in his Lehrbuch der Anatomie des Menschen (1938), but with numerous personal contributions, particularly related to embryological aspects. Thus, in the Prologue of its first edition, Orst-Llorca is very clear respect to this idea, and tells us:

\begin{abstract}
El biólogo debe considerar el cuerpo humano como un conjunto vivo y armónico... Esta orientación biológica de la Anatomía es ya antigua, y uno de sus principales propulsores fue BRAUS..Con ella se trata de destruir la tradición, según la cual el médico tiene de la Anatomía el recuerdo de una árida descripción de detalles, que relaciona exclusivamente con el inerte cadáver, y de conseguir, por el contrario, que la considere como el consejero que le ayude a conservar la integridad anatómicofuncional del organismo o a restablecerla si fue alterada... el médico debe ser hombre de Ciencia, extrayendo de la Embriología descriptiva o experimental o de la Anatomía comparada aquellos conocimientos que contribuyen a esclarecer no pocas disposiciones anatomofisiológicas de nuestro cuerpo... (The biologist must consider the human body as a unit, harmonic and alive... This biological consideration of the Anatomy is not new, and one of its main promoters was BRAUS... This orientation intends to destroy old views, according to which medical doctors remember Anatomy as a dry description of details, which they exclusively relates to the corpse instead of consider it as the adviser who helps them to preserve the anatomic and functional integrity of the organism or to reestablish them in case they were altered... the medical doctors of today must be men of Science, extracting from experimental or descriptive Embryology or from comparative Anatomy all those pieces of knowledge which may contribute to clarify not few anatomic and physiological dispositions in our body).
\end{abstract}

A lot of generations of Spanish-speaking medical doctors have been trained with this important textbook of Anatomy, written by one of the brightest Spanish scientists and pedagogues (see also 1954c, 1959c, 1961a, 1973b, 1978b) of his time, in spite of the extraordinary and difficult sociopolitical, economic and war circumstances he had to live. All of us have had the good fortune to be trained by him, cherish a timeless memory of his inspirational teachings and support.

\section{Biographic sources for Francisco Orts-Llorca (1905- 1993)}

Ebert J D (1960) YearBook 59 (1959-1960) Carnegie Institution of Washington, Department of Embryology, Baltimore.

Gómez-Santos M (1968) Francisco Orts-Llorca. In Cinco Grandes de la Ciencia Española, pp 157-182. Biblioteca Nueva.

Mendez D, Piqueras P M and Pérez-Llorca J (1974) Orts-Llorca: de la Anatomía a las raices de la vida. Biograma 1: 239- 274.

Orts-Llorca F (1947) Lista de títulos y méritos académicos. Imprenta Rimada. Cádiz.

Orts-Llorca F (1973) Nota necrológica sobre el Profesor Pedro Ara (1891-1973). Archivos de la Facultad de Medicina de Madrid 24: 248-251.

Orts-Llorca (1974) Curriculum vitae. Facultad de Medicina de Madrid.

Osacar E, Roque-Suárez A, Orts-Llorca F and Ara P (1962) Acto académico de 
entrega de los títulos de "Doctor Honoris Causa" a los eminentes profesores españoles Doctores Don Francisco Orts Llorca y Don Pedro Ara. Publicaciones de la Universidad de Córdoba (Argentina).

\section{Bibliography on Embryology and Teratology of Fran- cisco Orts-Llorca, in chronological order (1932-1990)}

(Note: We do not use abbreviations for journal titles because today many of them have changed or disappeared)

Orts-Llorca F (1932a) Contribution a l'étude de l'artère stapédienne chez l'embryon humain. Annales d'Anatomie Pathologique et d'Anatomie Normale MédicoChirurgicale 9: 684-686.

Orts-Llorca F (1932b) Lymphatiques des ganglions de la chaîne sympathique chez le nouveau-né. Annales d'Anatomie Pathologique et $d^{\prime}$ Anatomie Normal Médico-Chirurgicale 9: 818-820.

Orts-Llorca F (1932c) Les anomalies du poumon par défaut, absence partielle du poumon droit chez un nouveau-né humain. Annales d'Anatomie Pathologique et d'Anatomie Normal Médico-Chirurgicale 9: 820-825.

Orts-Llorca F (1933a) Quelques remarques a propos du developpement des arteres pulmonaires chez l'embryon humain. Annales d'Anatomie Pathologique et d'Anatomie Normale Médico-Chirurgicale 10: 935-936.

Orts-Llorca F (1933b) Contribución al estudio de las hernias diafragmáticas congénitas. Arquivo de Anatomia e Antropologia 16:1-32.

Orts-Llorca F (1933c) Algunas consideraciones sobre los derivados de los dos primeros arcos viscerales en los distintos vertebrados. Crónica Médica 2: 631 636.

Orts-Llorca F (1933d) L'artère stapédienne et la cause mécanique probable de son atrophie. Arquivo de Anatomia e Antropologia 16:199-207.

Orts-Llorca F (1933e) Contribución al estudio de los sextos arcos aórticos y de las arterias pulmonares. Gaceta Médica Española 7: 650-654.

Orts-Llorca F (1933f) Ein seltener Fall von Hernia diaphragmatica beim Hunde. Anatomischer Anzeiger 76: 272-276.

Orts-Llorca F (1934a) Über die Entwicklung der Arterienbogen beim Schweine. Zeitschrift für Anatomie und Entwicklungsgeschichte 102: 335-347.

Orts-Llorca F (1934b) Über die Entwicklung der caudalen Spinalganglien beim Menschen. Zeitschrift für Anatomie und Entwicklungsgeschichte 102: 462-480.

Orts-Llorca F.(1934c) Über regelwidrige Verbindungen der chorda dorsalis mit dem Medularrohre bei jungen menschlichen Embryonen. Anatomischer Anzeiger 81: 283-290.

Orts-Llorca F (1934d) Beschreibung eines menschlichen Embryo mit 4 Urwilbelpaaren. Zoologischer Anzeiger 103:765-792.

Orts-Llorca F (1936a) Patogenia de los gemelos y de ciertas monstruosidades que se observan en la especie humana Acta Clínica 1: 123-131.

Orts-Llorca F (1936b). Persistencia de la aorta descendente derecha del embrión. Contribución al estudio del desarrollo de las aortas dorsales en el embrión humano. Arquivo de Anatomia e Antropologia 18: 71-90.

Orts-Llorca $\mathrm{F}$ (1937a) Le système nerveux d'un embryon humain pathologique du premier mois. Archives d'Anatomie, d'Histologie et d'Embryologie normal et expérimentales 24: 279-294.

Orts-Llorca F (1937b) El ductus toracicus y las vias linfáticas colaterales del tórax en el Macacus Rhesus, con un estudio complementario sobre el desarrollo de estos vasos en el embrión humano. Anales de la Universidad de Valencia (Segunda época) 3: 19-96.

Orts-Llorca F (1938) Sobre un embrión humano patológico del primer mes. Folia Morphobiologica Hispanica 1: 21-36.

Orts-Llorca F (1941) Contribución al estudio de las espinas bifidas basada en hechos de embriología experimental. Arquivo de Anatomia e Antropología 21: 297-345.

Orts-Llorca F (1943) Erzeugung von Asymmetrien im Hühnerei durch Einwirkung von Testovirón. Wilhelm Roux Archives für Entwicklungsgmechanik der Organismen 142: 619-620.

Orts-Llorca F (1944a) Acción perturbadora del Testovirón y las sales de litio sobre los primeros estadíos del desarrollo en el embrión de pollo. Contribución al estudio de las asimetrías de origen experimental. Archivo Españolde Morfología
4: 131-201.

Orts-Llorca F, Mari Martínez M (1944b). Contribución al estudio del desarrollo de las arterias coronarias en el embrión humano. Arquivo de Anatomia e Antropología 23: 307-333.

Orts-Llorca F, Martínez-Rovira J L (1944c) La importancia de ciertos trastornos del desarrollo en la etiología de la siringomielia. Revista Clínica Española 14: 218226.

Orts-Llorca F (1944-1952) Anatomía Humana. Textbook in four volumes with five posterior editions (1959, 1963, 1972, 1977 and 1981). Editorial CientíficoMédica.

Orts-Llorca F (1946a) Etiología de la otocefalia. Archivo Español de Morfología 5 283-299.

Orts-Llorca F (1946b) Génesis de los Teratomas. Discurso leído en la solemne apertura del curso académico 1946-47 en la Universidad de Sevilla. Imprenta Rimada.

Orts-Llorca F, Mari-Martínez M (1948a) Malformación medular en un embrión humano de $25 \mathrm{~mm}$ y su probable importancia en la etiopatogenia de la heredoataxia. Revista Clínica Española 28: 40-44.

Orts-Llorca F (1948b) El Cortirón como causa de asimetría en el embrión de pollo. Arquivo de Anatomia e Antropologia 25: 281-294.

Orts-Llorca F, Martínez-Rovira J L (1948c) Variación del prosencéfalo de un embrión humano de 4 mm. Arquivo de Anatomia e Antropologia 26:115-122.

Orts-Llorca, F. (1948d) Evocación de placa y canal neural en el blastodermo de pollo por medio del testículo humano muerto por ebullición y desecado. Revista Española de Oto-neuro-oftalmología y Neurocirugía 40: 1-11.

Orts-Llorca F and Mari-Martínez M (1949) Malformacion del mesencéfalo (Apertura dorsalis mesencephali) en un embrión humano de $25 \mathrm{~mm}$. Archives Portugaises des Sciences Biologiques 10: 9-18.

Orts-Llorca F, Mari-Martínez M, López-Rodríguez A (1950a) Simelia y diastematomielia en un embrión de $15 \mathrm{~mm}$. Arquivo de Anatomia e Antropologia 27:107-118.

Orts-Llorca F, Duenas-Barrios A (1950b). Ulcus duodenal y páncreas anular Revista Clinica Española 36:407-409.

Orts-Llorca, F, López-Rodríguez, A (1951) La fermeture du foramen subseptale du coeur chez l'embryon humain. Comptes Rendus del'Association des Anatomistes (Nancy) 38: 774-776.

Orts-Llorca F, Mari-Martínez M (1952a) Contribución al estudio del desarrollo de corazón hasta el final del período somítico. Medicina Clínica 18: 102-110.

Orts-Llorca F (1952b). El divertículo gástrico yuxtacardial. Cirugía, Ginecología y Urología 3: 181-190

Orts-Llorca F (1952c) El desarrollo del testículo y la determinación sexual. Cirugía Ginecología y Urología 3: 264-275.

Orts-Llorca F (1952d) Embrión humano cíclope de 25 mm. Contribución al estudio de la ciclopía. Archivo Español de Morfología 9 Supp IV: 1-64.

Orts-Llorca F and Genis-Galvez J M (1953a) Vergleich der Kerngrößen der Netzhautzellen eines cyclopischen menschlichen Embryo von $22 \mathrm{~mm}$ und eines normalen des gleichen Entwicklungsstadiums. Zeitschrift für Anatomie und Entwicklungsgeschichte 117: 70-72.

Orts-Llorca, F (1953b) Organizadores, genes y hormonas en las primeras fases de desarrollo. Generalidades. Archivo Español de Morfología 10:193-205.

Orts-Llorca, F (1954a) Primer caso de atresia tricuspídea en un embrión humano de 16,5 mm. Revista Española de Cardiología 8: 81-110.

Orts-Llorca F (1954b) Hipófisis y suprarrenales en el período prenatal. Gazeta Medica Portuguesa 7: 215-220.

Orts-Llorca F (1954c) Anatomía funcional y fisiología del desarrollo. Revista de la Universidad de Madrid3: 147-173.

Orts-Llorca F (1955a) L'encéphale et l'œil chez deux embryons humains cyclopes de 35 et 47 jours respectivement. Acta Anatomica (Basel) 23: 379-385.

Orts-Llorca F (1955b) Pigomelie (parasitischer Pygopagus) bei einen 26 Tage alten Mädchen. Zeitschrift für Anatomie und Entwicklungsgeschichte 118: 417-426.

Orts-Llorca F and Genis J M (1956a) L'action de la Hyaluronidase sur le développement embryonaire du poulet. Acta Anatomica (Basel) 28: 287-302.

Orts-Llorca F (1956b) La Fisiología del Desarrollo y su importancia en Biología. Monografías Médicas Alhambra. Editorial Alhambra, SA. 
Orts-Llorca F (1956c) Introducción embriológica del tubo neural. In Sindromes neurológicos en las malformaciones del estuche cráneo-vertebral (Eds. S. Obrador and P. Albert) Editorial Paz Montalvo.

Orts-Llorca F (1956d) Los maestros desaparecidos: al Prof. Celestino da Costa. Boletim do Instituto de Patologia Médica de Lisboa, 11: 75-76.

Orts-Llorca F y López Rodríguez A (1957a) La curva dorsal en los embriones humanos del período somítico. Cirugía, Ginecología y Urología 11: 1-6.

Orts-Llorca F (1957b) Der Nervus opticus (fasciculus opticus) und Fissura choroidea bei Zyclopie. Acta Anatomica (Basel) 30: 565-574.

Orts-Llorca F, Genis Galvez J M (1958a) On the morphology of the primordium of the thyroid gland in the human embryo. Acta Anatomica (Basel) 33: 110-121.

Orts-Llorca F, Recasens $\mathrm{E}$ (1958b) Un cas de diplogénèse postérieure incomplète chez une femme adulte. Acta Anatomica (Basel) 35: 179-192.

Orts-Llorca, F (1958c) Embrión humano de 14 pares de somitos. Cirugía, Ginecología y Urología 12: 226-232.

Orts-Llorca F, Genis-Galvez J M, Ruano-Gil, D. (1959a) Malformations encéphaliques et microphtalmie gauche après la section des vaisseaux vitellins gauches chez l'embryon de poulet. Acta Anatomica (Basel) 38: 1-34.

Orts Llorca F, López Rodríguez A (1959b) Interrupción de la aorta, ausencia de la vena cava caudal con múltiples malformaciones cardiacas en un embrión humano de 22 mm. Archivo Español de Morfología 16: 103-125.

Orts-Llorca F (1959c) La Biología Humana y la experimentación pedagógica. Archivos de la Facultad de Medicina de Zaragoza 7:1075-1087.

Orts-Llorca F, Genis-Galvez J M (1960a) Pliegues congénitos de la retina, Retinal Septa o Ablatio falciformis retina. Mecanismo patogénico. Archivos de la Sociedad Oftalmológica Hispano-Americana 20: 91-110.

Orts-Llorca F, Genis-Galvez J M (1960b) Experimental production of retinal septa in the chick embryo. Diferentiation of pigment epithelium into neural retina. Acta Anatomica (Basel) 42: 31-70.

Orts-Llorca F, Jiménez-Collado J, Ruano-Gil D (1960c) La fase plexiforme del desarrollo cardíaco en el hombre. Embriones de $21+/-1$ día. Anales de/ Desarrollo 8: 79-98.

Orts-Llorca F. (1961a) La enseñanza de las disciplinas básicas en las Facultades de Medicina. Medicamenta 364: 3-8.

Orts-Llorca F, Murillo-Ferrol N (1961b) Determination und Differenzierung der Riechplakoden beim Hühnerembryo. Wilhelm Roux Archives für Entwick/ungsgmechanik der Organismen 153: 434-442.

Orts Llorca F (1962a). Un momento decisivo en nuestro devenir biológico. Archivos de la Facultad de Medicina de Madrid1: 181-186.

Orts-Llorca F (1962b) La determinación y diferenciación de la vesícula auditiva. Revista Española de Oto-Neuro-Oftalmología y Neurocirugía, 119:1-7.

Orts-Llorca F (1962c) Injertos cardíacos en el embrión de pollo. Nota previa. Archivos de la Facultad de Medicina de Madrid1: 72-77.

Orts-Llorca F, Ruano-Gil D, Jiménez-Collado J (1962d) Malformaciones de la parte caudal de la columna vertebral. Mecanismo patogenético. Observación en un embrión de 17,25 mm. Anales del Desarrollo 10: 337-347.

Orts-Llorca F, Ruano-Gil D, Quero-Morente M (1962e) Un caso de cor triatriatum. Persistencia del seno pulmonar. Anales del Desarrollo 10: 349-355.

Orts-Llorca F, Ruano-Gil D, Jiménez-Collado J (1962f) Malformaciones en un embrión humano de 17,25 mm. Archivos de la Facultad de Medicina de Madrid 2: 75-91.

Orts-Llorca F (1962g) Morfogénesis del corazón. Revista de la Facultad de Ciencias Médicas (Córdoba, Argentina) 4: 20-37.

Orts-Llorca F Jiménez-Collado J, Ruano-Gil D (1962h) Arrinencefalia con monorrinia en un embrión humano de 17,25 mm. Anales del Desarrollo 10: 529-537.

Orts-Llorca F (1962i). Morfogénesis cardiaca. Análisis causal. Boletín de la Academia Nacional de Medicina de Buenos Aires 40: 227-228.

Orts-Llorca F (1963a). Influencia del endodermo sobre la diferenciación cardiaca en los estadíos precoces del desarrollo en el embrión de pollo. Archivos de la Facultad de Medicina de Madrid3: 407-413.

Orts-Llorca F (1963b). Malformaciones congénitas: etiología y mecanismo patogénico de las anormogénesis. Cirugía, Ginecología y Urología 17:139-173.

Orts-Llorca F (1963c) Análisis experimental del factor endodérmico en la determinación y diferenciación cardiaca del embrión de pollo. Anales del
Desarrollo 11: 3-17.

Orts-Llorca F (1963d) Influence of the endoderm on heart differentiation during the early stages of development of the chicken embryo. Wilhelm Roux Archives für Entwicklungsgmechanik der Organismen 154: 533-551.

Orts-Llorca F (1963e) Influence de l'entoblaste dans la morphogenèse et la différenciation tardive du coeur du poulet. Acta Anatomica (Basel)52: 202-214.

Orts-Llorca F, Murillo-Ferrol N (1963f). Duplicites experimentales des membres chez l'embryon de poulet. Comptes Rendus de l'Association des Anatomistes 122: 294-303.

Orts-Llorca F, Jiménez-Collado J (1964a) Dos embriones humanos con ciclopía completa. Cristalino único. Archivos de la Facultad de Medicina de Madrid5: 207-211.

Orts-Llorca F, González-Santander R (1964b). Modelo de un corazón de embrión de pollo injertado en la cavidad celómica de un huésped. Archivos de la Facultad de Medicina de Madrid 5: 211-215.

Orts-Llorca $F$ (1964c) Influence of the ectoderm on heart differentiation and placement in the chicken embryo. Wilhelm Roux Archives für Entwicklungsgmechanik der Organismen 155: 162-180.

Orts-Llorca F (1964d) What are the factors which lead to the fusion of the two heart primordia? An experimental analysis. Wilhelm Roux Archives für Entwicklungsgmechanik der Organismen 155: 437-450.

Orts-Llorca F (1964e) Les facteurs déterminants de la morphogenèse et de la différenciation cardiaque. Comptes rendus de l'Association des Anatomistes 123: $123-126$.

Orts-Llorca F, Jiménez-Collado J (1964f) El volúmen nuclear en la ciclopía humana. Archivos de la Facultad de Medicina de Madrid6: 299-304.

Orts-Llorca F (1965a) Does the nervous system posses any influence on heart determination and differentiation? Acta Anatomica (Basel) 60: 107-121.

Orts-Llorca F, Murillo-Ferrol N L (1965b) Action of the rhombencephalon on the differentiation of the auditive placodes. Chronology of its influence. Wilhelm Roux Archives für Entwicklungsgmechanik der Organismen 156: 363-367.

Orts Llorca F, Ruano-Gil D (1965c) Influence of the endoderm on heart differentiation. Wilhelm Roux Archives für Entwicklungsgmechanik der Organismen 156: 368-370.

Orts-Llorca F, Jiménez-Collado J (1966a) Determinación de la polaridad cardíaca en el embrión de pollo. Archivos de la Facultad de Medicina de Madrid10: 121126.

Orts-Llorca F (1966b) Embriología de la piel. In Dermatología (Ed, J Gay-Prieto) Editorial Científico-Médica.

Orts Llorca F, Ruano-Gil D (1967a) A causal analysis of the heart curvatures in the chicken embryo. Wilhelm Roux Archives für Entwicklungsgmechanik der Organismen 158: 52-63.

Orts-Llorca F, Jiménez-Collado J (1967b) Determination of heart polarity (arteriovenous axis) in the chicken embryo. Wilhelm Roux Archives für Entwicklungsgmechanik der Organismen 158: 147-163.

Orts-Llorca F, Jiménez-Collado J (1967c) Potencial morfogenético y organización regional del area cardiaca en el embrión de pollo. Anales del Desarrollo 14: 3 13.

Orts-Llorca F (1967d) El proceso de la diferenciación y su importancia en Biología. Archivos de la Facultad de Medicina de Madrid11: 347-370.

Orts-Llorca F (1967e) Citodiferenciación cardíaca, miofibrillas. Nota previa. Archivos de la Facultad de Medicina de Madrid11: 373-374.

Orts-Llorca F, Jiménez-Collado J (1967f) La técnica de isótopos radioactivos en Embriología. Archivos de la Facultad de Medicina de Madrid12: 387-394.

Orts-Llorca F, Jiménez-Collado J (1967g) Organisation régionale de l'aire cardiaque chez l'embryon de poulet. Bulletin de I'Association des Anatomistes (Nancy) 139: 952-955.

Orts-Llorca F, Jiménez-Collado, J (1968a) A radioautographic analysis of the prospective cardiac area in the chick blastoderm by means of labeled grafts. Wilhelm Roux Archives für Entwicklungsgmechanik der Organismen 160: 298312.

Orts-Llorca F, Jiménez-Collado J (1968b) Evolución de los injertos heterólogos marcados con tymidina tritiada en el área cardíaca del blastodisco del pollo. Archivos de la Facultad de Medicina de Madrid14: 395-397. 
Orts-Llorca F, Jiménez-Collado J (1969a) The development of heterologous grafts, labeled with thymidine-3H in the cardiac area of the chick blastoderm. Developmental Biology 19: 213-227.

Orts-Llorca F, Navarrina-Gamez F (1969b) Regularización, diferencias y efectos de las hemiextirpaciones del esbozo encefálico en las aves en estadios 5, 8, 10 , 11 y 13 de Hamburger y Hamilton. Revista Medica de Galicia 7: 395-406.

Orts Llorca F, González-Santander R (1969c) Estudio electromicroscópico de la primera aparición y desarrollo de los miofilamentos cardiacos (miofibrillogenesis) en el embrión de pollo. Revista Española de Cardiología 22:537-568.

Orts-Llorca F, Jiménez-Collado J (1969d) Morfogénesis de la bóveda palatina. Sus malformaciones. Archivos de la Facultad de Medicina de Madrid15: 213-228.

Orts-Llorca F, Ruano-Gil D (1970a) Curvature of the heart: its first appearance and determination. Acta Anatomica (Basel) 77: 454-468.

Orts-Llorca F, Jiménez-Collado J (1970b) The development of heterologous graft of cardiac area (labeled with tymidine-3H) to the caudal area of the chick blastoderm. Archives d'Anatomie, Histologie et Embryologie normal et expérimentales 53: 113-124.

Orts-Llorca F (1970c) Desarrollo del corazón. In Biología del Desarrollo. Fundamentos de Embriología (Ed, José M Genis-Gálvez). Editorial Espaxs.

Orts-Llorca F. (1970d) Embriología de la columna vertebral. In Semana sobre la columna vertebral. Publicaciones Liade.

Orts-Llorca F (1970e) La nicotina y las malformaciones congénitas. In Coloquio sobre tabaco y nicotina. Editorial Otero.

Orts-Llorca F (1971a) La interacción epitelio-mesenquimal, proceso fundamental en la morfogénesis y diferenciación de los órganos. In Libro Homenaje al Profesor B. Lorenzo Velázquez. Editorial Otero.

Orts-Llorca F, Jiménez-Collado J (1971b) Desarrollo y diferenciación de los injertos de esbozos de miembro de la codorniz al embrión de pollo. Caracteres nucleolares de las células de la codorniz (Coturnix Coturnix Japonica). Archivos de la Facultad de Medicina de Madrid 20: 61-74.

Orts-Llorca F, Jiménez-Collado J (1971c) Regulation of the embryo after the extirpation of Hensen's node. Consequences on the differentiation of the otic placode. Archives d'Anatomie, Histologie et Embryologie normales et expérimentales 54: 1-12.

Orts-Llorca F (1972) Un ejemplo de la importancia del microambiente en Biología. In Libro Homenaje a Aranguren. Ediciones Revista de Occidente.

Orts-Llorca F (1973a) Propiedad inductora del nudo primitivo de la codorniz (Coturnix coturnix japonica) en el blastocisto del pollo (Gallus gallus). Archivos de la Facultad de Medicina de Madrid 24: 55-58.

Orts-Llorca F (1973b) La moderna institución en Ciencias Morfológicas. Archivos de la Facultad de Medicina de Madrid 24: 349-357.

Orts Llorca F, Murillo-Ferrol N (1974a). Action inhibitrice des cellules de l'ébauche neurale présomptive sur les cellules à potentialité cardiaque. Bulletin de /' Association des Anatomistes (Nancy) 58: 1153.

Cuevas P, Orts-Llorca F (1974b) Induction primaire chez le jeune blastoderm de poulet (Gallus gallus) par la greffe du noeud de Hensen de caille (Coturnix coturnix japonica). Acta Anatomica (Basel) 89: 423-430.

Cuevas P, Orts-Llorca F (1974c) Induction properties of fragments of Hensen 's node. Archivos de Neurobiología (Madrid) 37: 331-336.

Cuevas P, Orts-Llorca F (1974d). Hallazgos personales sobre la estructura de las células cristalinianas del embrión de Golondrina (Hirundo rustica). Archivos de la Facultad de Medicina de Madrid 25: 49-51.

Cuevas P, Orts-Llorca F (1974e).Ultraestructura del núcleo de neuroblastos encefálicos del embrión de golondrina (Hirundo rustica). Anales de/ Desarrollo 18: 51-52.

Domenech Mateu J M, Orts-Llorca F (1974f) Action de la l-asparaginase sur l'embryon de poulet (Gallus domesticus). Bulletin de /'Association des Anatomistes (Nancy) 58:163-172.

Orts-Llorca F, Cuevas P, Lemus D (1975a) Evolution de la greffe homotypique de l'aire cardiaque présomptive de caille chez le poulet. Bulletin de I'Association des Anatomistes (Nancy) 59: 719-724.

Orts-Llorca F (1975b) El descubrimiento del huevo de los mamíferos y sus principales características estructurales. In Libro Homenaje al Profesor Vara López. Editorial Sever-Cuesta.

Orts-Llorca F. (1975c) La Embriología actual a partir de 1914. In Historia Universal de la Medicina, Vol 7 (Ed, Pedro Laín-Entralgo). Editorial Salvat.

Doménech-Mateu J M, Orts-Llorca F (1975d) Origen insólito de la arteria del nodo sino-atrial a partir de la arteria circunfleja auricular izquierda.-Revista Española de Cardiología 28: 357-360.

Doménech-Mateu J M, Orts-Llorca F (1976a) Arterial vascularization of the sinuatrial node in the embryonic rat heart. Acta Anatomica (Basel) 94: 343-355.

Guijarro de Pablos J E, Orts Llorca F, Ribes-Blanquer R (1976b) New evidences on the first appearances of the semicircular duct, cristae and cupulae in human embryos. Reproducción 3:67-72.

Orts-Llorca, F. (1977a) Morphogenesis of the cerebellum. Anales de la Real Academia Nacional de Medicina (Madrid) 94:329-343.

Orts-Llorca F, Puerta-Fonollá A J, Acín-García F (1977b) Morfogénesis de los tubérculos mamilares (corpora mamillaria). Archivos de Neurobiología (Madrid) 40: 139-164.

Puerta-Fonollá A J, Orts-Llorca F (1978a) Origine et développement du septum primum. Acta Anatomica (Basel) 100: 250-257.

Orts-Llorca F (1978b) Enseñanza de la Embriología y Teratología. Archivos de la Facultad de Medicina de Madrid34: 9-15.

Orts-Llorca F (1978c) Study of the fundamental properties of the cells of the cardiac rudiment. Analysis by means of cellular disaggregation and aggregation. In Medical and Biological Papers. Fundación Rodriguez Pascual.

Orts-Llorca F, Doménech-Mateu J M, Puerta-Fonollá A J (1979a) Inervation of the sinu-atrial node and neighbouring regions in two human embryos. Journal of Anatomy 128: 365-375

Paomar V M, Puerta-Fonollá A J, Orts-Llorca, F. (1979b) Morfogénesis del estribo. Acta Otorrinolaringica Experimenta/30: 133-142.

Orts Llorca F (1979c) La inducción en las aves. El Testoviron, un poderoso inductor. Anales de la Real Academia Nacional de Medicina (Madrid), 96: 31-52.

Orts-Llorca F, Puerta-Fonollá A J, Sobrado-Pérez J (1980a) The morphogenesis of the ventricular flow pathways in man. Archives d'Anatomie, Histologie et Embryologie normales et expérimentales 63: 5-15.

Orts-Llorca F, Doménech-Mateu J M (1980b) Testoviron is a potent inducer of chick blastoderm. Acta Anatomica (Basel) 106: 415-423.

Orts-Llorca F, Domenech-Mateu J M (1980c) Über induction von Neuralplatten durch Implantation von Testoviron in der Keimscheibe des Hühnchens. Verhandlungen der Anatomischen Gesellschaft 74: 359.

Orts-Llorca F (1980d) Dos estructuras microscópicas del cerebro posterior: locus coeruleus y area postrema. Anales de la Real Academia Nacional de Medicina (Madrid) 97: 37-51.

Orts-Llorca F, Puerta-Fonollá A J, Sobrado-Pérez J (1981a), Morphogenesis of the ventricular flow pathways in man (Bulbus Cordis and Truncus Arteriosus). In Perspectives in Cardiovascular Research, Vol 5: "Mechanism of Cardiac Morphogenesis and Teratogenesis"(Ed, T Pexieder). Raven Press.

Orts-Llorca F (1981b) La somitogenèse chez l'embryon humain: apparition des myotomes. Bulletin de I'Association des Anatomistes (Nancy) 65: 467-482.

Orts-Llorca F, Puerta-Fonollá A J, Sobrado J (1982a) The formation, septation and fate of the truncus arteriosus in man. Journal of Anatomy 134: 41-56.

Orts-Llorca F (1982b) Transposition of the great arteries or ventriculo-arterial discordance in a $19 \mathrm{~mm}$ human embryo. Anales de la Real Academia Nacional de Medicina (Madrid) 99: 343-356.

Ruano-Gil D, Orts-Llorca F, Götzens V J, Berástegui C (1983a) A cyclopian human embryo of $12 \mathrm{~mm}$ with single crystalline lens. Archivio Italiano d'Anatomia ed Embriologia 88:311-321.

Orts-Llorca F, Domenech-Mateu J M, Puerta-Fonollá A (1983b), Trasposición típica completa de las grandes arterias (TGA) en un embrión humano de $19 \mathrm{~mm}$ : una nueva teoría sobre su embriogénesis. Revista Española de Cardiología 36: 81-88.

Orts-Llorca $F$ (1984) Embriones y fetos humanos de diversas Universidades españolas. Editorial Universidad Complutense.

Orts-Llorca F (1985) Los monstruos bicéfalos (diplogénesis anterior). Perspectivas de supervivencia. Anales de la Real Academia Nacional de Medicina (Madrid) 102: $431-444$.

Orts-Llorca F, López-Rodríguez A, Puerta-Fonollá A J, Díaz-González J L (1986) Comunicación entre atrium dextrum y ventriculus sinister: Explicación 
embriológica. Revista Española de Cardiología, 39, Supp 1: 3-11.

Orts-Llorca F (1988) El factor neural del desarrollo (NGF) y la historia de su descubrimiento. Anales de la Real Academia Nacional de Medicina (Madrid) 105: 483-488.

Orts Llorca F (1990). Cómo somos antes de nacer. Editorial Doyma, S A, Barcelona.

\section{Acknowledgements}

We would like to express our deep appreciation to the help given to us by Dr Donald Brown, from the Department of Embryology of the Carnegie Institution of Washington in Baltimore (USA), by Dr Stefan Nonchev from the University of Grenoble (France), by Dr Ma Concepción MartínezÁlvarez from the Complutense University of Madrid (Spain) and, particularly, to Mrs Ana Álvarez-Castrosín, from the Department of Anatomy and Embryology of the Complutense University Medical School of Madrid (Spain), former secretary and collaborator of professor Francisco OrtsLlorca during many years. Mrs Anne-Marie Chalmandrier, from the Service de Documentation de la Bibliothèque de la Facultè de Médicine de Nancy (France), Mrs Elvira Gimeno-Sieres from the Instituto de Historia de la Medicina y de la Ciencia López-Piñero (University of Valencia-CSIC, Valecia, Spain), Mrs Rosario Garcia, Librarian of the University of Valencia Medical School (Spain), Mrs $M^{a}$ Ángeles Langa, Librarian of the Cajal Intitute, CSIC of Madrid (Spain), Mrs Sonsoles Celestino-Angulo, Librarian of the University of Seville (Spain) and Mr Antonio Sánchez, Librarian of the Hemerotheca of University Hospital of San Cecilio of Granada (Spain) have help to us a lot to complete the bibliography of Prof. Orts-Llorca. This work has been supported by a Grant of the Spanish Ministry of Education and Science (BFU200766610) and a Research Group Grant of the University of the Basque Country (GIU08/04) to J.A.

\section{References}

ANGETTER D C (2000) Anatomical science at University of Vienna 1938-1945. Lancet 355: 1454-1457.

ARÉCHAGA J (1989) In search of embryonic inductors. An interview with Sulo Toivonen in his 80 th birthday. Int J Dev Bio/33: 9-14.

ARÉCHAGA J, OLAGÜE G, GARCÍA-BALLESTER L (1976) La Embriología en la España del siglo XVIII. In La Introducción de la Teoría Celular en España. Servicio de Publicaciones de la Universidad de Granada, pp 20-32.

ARÉCHAGA J, OLAGÜE G, GARCíA-BALLESTER L (1976) La Embriología en la España del siglo XIX, anterior a la obra de Mariano López Mateos. In La Introducción de la Teoría Celular en España. Servicio de Publicaciones de la Universidad de Granada, pp. 32-40.

BORN G (1883) Die Plattenmodelliermethode. Arch mikroskop Anat 22: 584-599.

FÄSSLER P (1996) Hans Spemann (1869-1941) and the Freiburg School of Embryology. Int J Dev Biol 40: 49-57.

FISCHEL A (1929) Lehrbuch der Entwicklung des Menschen. Springer.

GHYSEN A (1998) Developmental Biology of Drosophila. Int J Dev Bio/42: 229540.

GHYSEN A (2009) Ontogeny of an adventurous mind. An Interview with Antonio García-Bellido on his contributions to Developmental Genetics. Int J Dev Biol 53: 1277-1290. (doi: 10.1387/ijdb.072384ag).

GROSSER O (1922) Zur Kenntnis der Trophoblastschale bei jungen menschlichen Eiern. Z Anat Entwicklungsgesch 66: 179-198.

HAMBURGER V (1996) Memories of professor Hans Spemann's Department of Zoology at the University of Freiburg, 1920-1932. Int J Dev Bio/40: 59-62.

HERTIG A T, ROCK J, ADAMS E C AND MULLIGAN W J (1954) On the preimplantation stages of the human ovum: a description of four normal and four abnormal specimens ranging from the second to the fifth day of development. Contrib Embryol Carnegie Inst 35: 199-220.
HIS W (1887) Über die Methoden der plastischen Rekonstruktion und über deren Bedeutung für Anatomie und Entwicklungsgeschichte. Anat Anz 2: 382-394.

HOPWOOD N (2002) Embryos in Wax. Models from the Ziegler Studio. Cambridge University Press.

HOPWOOD N (2007) A history of normal plates, tables and stages in vertebrate embryology. Int J Dev Bio/51: 1-26.

KEIBEL F, MALL F P (1910-1912) Human Embryology. Lippincott.

LAÍN-ENTRALGO P (1978) Cajal por sus cuatro costados. In Santiago Ramón y Cajal (1952-1934). Colección "Expedientes Administrativos de Grandes Españoles", Número 2 (Ed. Manuel Núñez-Pérez). Servicio de Publicaciones del Ministerio de Educación y Ciencia, pp 17-65.

LE DOUARIN N M (1969) Particularités du noyau interphasique de la Caille japonaise (Coturnix coturnix japonica). Bull Biol France Belgique 103: 435-452.

LÓPEZ-PIÑERO J M (1971) Carlos Silóniz y Ortiz. Asclepio 23:103-112.

LÓPEZ-PIÑERO J M (2006) Santiago Ramón y Cajal. Publicacions de la Universitat de València \& Editorial Universitaria de Granada.

LÓPEZ-PIÑERO J M, GLICK T F, NAVARRO-BROTÓNS E, PORTELA E (1983) Diccionario Histórico de la Ciencia Moderna en España. 2 Vols. Editorial Península.

LÓPEZ-PIÑERO, J M, BUJOSA, F AND TERRADA, M L (1979) Martín Martínez, 1706: Estudio anatomopatológico de un caso de cor protusum. In Clásicos españoles de la Anatomía Patológica anteriores a Cajal. Cuadernos Valencianos de Historia de la Medicina y de la Ciencia, num. 21, Serie B (textos clásicos). Cátedra e Instituto de Historia de la Medicina de Valencia, pp 89-91.

MARCO-CUELLAR R, ARÉCHAGA J (2009) Early bases of modern Embryology in Spain: Microscopical Anatomy and the introduction of Cell Theory and Histology in their scientific and social European context. Int J Dev Bio/53: 11231143 (doi: 10.1387/ijdb.093020rm)

MARTÍNEZ-ARIAS M (2009) A perspective on the development of Genetics in Spain during the XX Century. Int J Dev Bio/53: 1179-1191 (doi: 10.1387/ ijdb.082811am).

MOSCONA A, MOSCONA H (1952) The dissociation and aggregation of cells from organ rudiments of the early chick embryo. $J$ Anat 86: 287-301.

OCHOA S (1995) Preface to the $13^{\text {th }}$ edition of $S$. Ramón y Cajal, Reglasy Consejos sobre Investigación Científica. Los Tónicos de la voluntad. Colección Austral. Editorial Espasa-Calpe.

ORTEGA Y GASSET J (1906) La Ciencia Romántica. Newspaper El Imparcial, June 4, Madrid.

ORTEGA Y GASSET J (1908) Asamblea para el progreso de las ciencias. Newspaper El Imparcial, July 28, Madrid.

OTERO-CARVAJAL L E (2001) La destrucción de la ciencia en España. Las consecuencias del triunfo militar de la España franquista. Hist Comun Soc 6: 149-186.

PERNKOPF E AND PICHLER A (1937-1960) Topographische Anatomie des Menschen. Lehrbuch und Atlas der Regionär-Stratigraphischen Präparation. Urban und Schwarzenberg.

PETER K (1922) Rekonstruktionsmethoden. In Abderhalden, E. (Ed) Handbuch der biologischen Arbeitmethoden.nUrban und Schwarzenberg.

ROUVIÈRE H (1932) Anatomie des Lymmphatiques de l'Homme. Masson et Cie Éditeurs.

SANDER K, FAESSLER P E (2001) Introducing the Spemann-Mangold organizer: experiments and insights that generated a key concept in developmental biology. Int J Dev Bio/45: 1-11.

VOGT W (1929) Gestaltungsanalyse am Amphibienkeim mit ortlicher Vitalfarbung. II. Teil. Gastrulation und Mesodermbildung bei Urodelen und Anuren. Wilhelm Roux Arch Entwicklungsgmech 120: 384-706.

VON MOLLENDORFF W (1921) Über das jüngste bisher bekannte menschliche Abortives (Ei SCH). Ein Beitrag zur Lehre von der Einbettung des menschlichen Eies. Z Anat Entwicklungsgesch 62: 352-405.

WILLIAMS D J (1988) The history of Eduard Pernkopf's Topographische Anatomie des Menschen. J Biocommunicat 15: 2-12. 
Further related reading, published previously in the Int. J. Dev. Biol.

Early bases of modern Embryology in Spain: Microscopical Anatomy and the introduction of Cell Theory and Histology in their scientific and social European context

Roberto Marco-Cuellar( $\dagger$ ) and Juan Aréchaga

Int. J. Dev. Biol. (2009) 53: 1123-1143 (doi: 10.1387/ijdb.093020rm)

History and status of embryology and developmental biology at Polish Medical Faculties and Schools

Hieronim Bartel

Int. J. Dev. Biol. (2008) 52: 141-146

From field to gel blot: teaching a holistic view of developmental phenomena to undergraduate biology students at the University of Tokyo.

Takashi Ariizumi and Makoto Asashima

Int. J. Dev. Biol. (2003) 47: 93-97

The organizer concept and modern embryology: Anglo-American perspectives.

T J Horder

Int. J. Dev. Biol. (2001) 45: 97-132

A history of mammalian embryological research.

$\mathrm{H}$ Alexandre

Int. J. Dev. Biol. (2001) 45: 457-467 [Abstract] [FullText]

A short history of the British Society for Developmental Biology.

J M Slack

Int. J. Dev. Biol. (2000) 44: 79-83

The "Stazione Zoologica Anton Dohrn" and the history of embryology.

B Fantini

Int. J. Dev. Biol. (2000) 44: 523-535.

\section{THE INTERNATIONAL JOURNAL OF DEVEOPPMENTAJ DOU 012

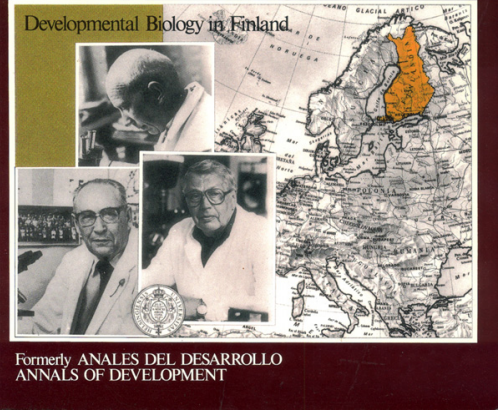

5 yr ISI Impact Factor $(2008)=3.271$

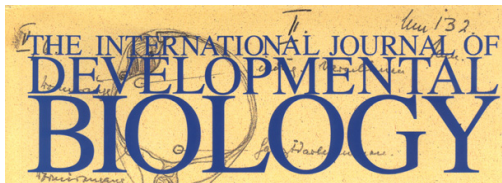

Volume 45 No. 1 Special issue

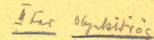

its
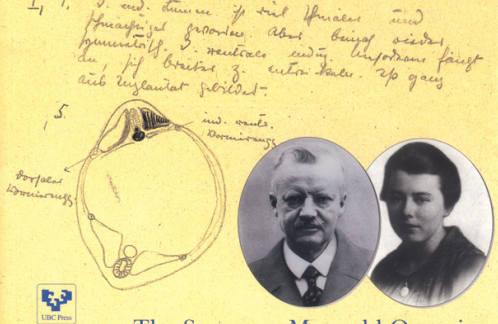

The Spemann-Mangold Organizer 